\title{
Son preference and contraceptive practice among tribal groups in rural South India
}

\author{
Sathiya Susuman Appunni
}

\begin{abstract}
This paper examines the son preference and contraceptive practice among tribal groups in rural south India. Parents' preferences for the sex of their children have constituted an important theme in population and social research over the past three decades. Data were collected from a household survey of 398 currently married women of reproductive age group (15-49) from four taluks in the Nilgiris District of rural Tamilnadu are selected with respect to the different tribal communities. Cross tabulation and logistic regression analysis was carried out for finding out relationships between the socio-economic, demographic variables on contraceptive practice. The use of contraceptive practice by tribal groups in rural areas is strongly linked to individual and household socio-economic and demographic variables. Findings shows that the expectation that a son will provide financial support in old age is strongly associated with the response that a son is important. Son preference is slightly more among the tribal women, particularly among the users of spacing method who are more among those preferring the sons. Some of the socio-economic variables like education of husband and occupation have shown negative influence on higher fertility and positive influence on contraceptive use among the tribal women. It is proposed that there is need for more comprehensive on tribes in different areas in state and in the Indian nation to explicitly bring out the son preference attitudes of tribal people, which have an impact on their fertility and family planning practices.
\end{abstract}

\section{Introduction}

The present study is an attempt to find out the reproductive behavior in relationship to their son preference and an answer to the general query - how the tribal communities differ from the general population with regard to this and their various socio-economic and demographic characteristics while inhabiting in the same ecosystem. Son preference is one of the reasons given for high fertility and low acceptance of family planning in many developing nations. Such a preference is believed to have a strong effect on the number of additional children parents have near and above the desired minimum size. Adoption or non-adoption of family planning method eventually depends on their achieved sex preference of children (Krishnamoorthy, 1974; Coombs et al., 1975; Krishnan, 1993; Rajaretnam and Deshpande,1994, 1995; Rajan et al., 1996; Muthurayappa et al., 1997; Arnold et al., 1998; Sathiya Susuman, 2000). At the same 
time, son preference and contraceptive practice are used with related suitable variables on some other groups. Wives in the nuclear families have higher fertility than those in joint families in tribal communities. It was also found the higher is the number of diseased children in a family the higher is the number of births reported. In some tribal societies of south Rajasthan the birth of a son is a mater of great jubilation and a family is considered to be incomplete in the sons absence and the mother who can not give birth at least to a son is a down trodden, and worthless creature Varadarajan (1981). Further it was also found that over 61 per cent expressed a preference for at least two male children and 21 percent desired more than two male children. Demographic and socio-cultural aspects of the tribes of Manipur among 100 families of various tribal groups and showed that there is a strong association between sex ratio at birth and the age and also the parity of women. Marriage and divorce were common among the tribes but it varies in degrees according to the idiosyncrasy of each tribe (Sadasiva Rao, 1977).

Almost all the women folk were afraid of Tubectomy because they thought it is dangerous and fatal to their health. Government or non- government agencies should explain them about the advantage and benefits of such program to clear their fears; appropriate population/health education should be given to them. Government must take up suitable housing schemes to provide pucca houses to them as early as possible. As the social participation is low, suitable steps should be taken to increase their participation in public bodies and institutions (Gurusamy, 1988). Fertility differentials, child mortality and family planning practices between two tribal groups in Luknow, India, a majority of the tribal groups 87 per cent and 67 per cent were living in joint family units; two-third of the tribal women were without schooling and the extent of indebtedness was high among both groups. Lower mean age at marriage among the wives of the two groups. Lower mean age at first birth, an average women gave a higher fertility level children and a higher ideal family size (Saxena, 1982). The acceptance and practice of family planning by the eligible couples depends to a very large extent on their awareness and knowledge regarding family planning methods, availability of services and favorable attitude towards family planning practices (Gurumurthy, 1986; Karkal Pause, 1979; Nag, 1991). The validity of the concept those tribes had a higher birth rate than the general population and the socio-cultural factors were responsible for the higher fertility among tribes. Two indicators of sex preference were used in the study such as the ideal number of sons and ideal number of daughters in a family. More balanced view concerning the ideal number of sons and daughters among the tribal women. The women do not have any special preference for either boys or girls (Repetto, 1972). The tribal society does not suffer from the compulsion to get married and have children, preferably a son. The tribal neither believe in rebirth nor believe in the theory of transmigration of soul. A number of studies in India showed that parents like to depend on their sons for old age security than their daughters. The cost of bringing up children up to age 15 does not seem to vary much between sons and daughters. However, the expectations from sons appeared to be more as compared to the daughters. The review of related literature leads us to conclude that the theoretical explanations advanced for some expected relationship between level of development socio-economic and cultural and value of children are sound. But the empirical relationship obtained in various setting always does not support the expected relationships. It is more so in the case of individual characteristics 
of the parents and value of children. The differentials in the (fertility differentials) level are due to differentials in the value of sons and daughters child, which are likely to be different under Indian context (Kuriyan, 1982; Sarma et al., 1974).

Both the boys and girls were perceived as contributing rather differently to these basic values. Respondents of both sexes perceived boys contribute to the satisfaction of a greater number of values and needs than girls. Financial security, being accepted by others, having a happy home, personal achievement and carrying on the family name were all values that respondents associated more with boys than with girls (Sathiya Susuman, 2000). The patterns observed, however, are by no means uniform throughout India and they can be expected to continue to decline. The preference for sons that has been observed to varying degrees in every part of India has been showed to have an adverse effect on both fertility behavior and sex differentials in child mortality (Krishnamoorthy, 1974). The desire for sons discourages some couples from discontinuing childbearing after reaching their desired number of children because they have not yet had their minimum desired number of sons (Vlassoff et al., 1980). Tribal communities of various countries and societies are using contraception for limit their family size. While the same, couples has been desired more number of children, irrespective of the sex. Most of the tribal couples want at least on son for various reasons. This might be traditional or cultural system. When couples have achieved desired number of sex particularly sons, they adopt sterilization from government hospital or health centre or other temporary methods or usually tribal women are using herbal medicine or home made contraception (Sathiya Susuman, 2000). It is necessary to study the son preference and contraceptive practice among rural south Indian tribal groups. The major aim of the study is to examine the son preference and contraceptive practice among various groups of tribal communities, it is important that we consider with under developed community groups. To this study, the tribal women were compared with respect to their influence of socio-economic and demographic variables on son preference and contraceptive practice in rural areas.

\section{Data and method}

In rural tribal communities of 398 currently married women in the age group of 15-49 with at least one living child are considered suitable for collection of data in rural Nilgiris district of Tamilnadu State. Structured questionnaire was used for data collection. The investigator was able to visit and interview only 398 houses as their households are residing in far away distance, which could not be reached easily. The purpose was to compare the differentials in their background characteristics, which may have an influence on son preference and reproductive behavior. Although pre-tested questionnaires were the main instruments used, qualitative information was gathered informally to supplement the findings of the inquiry. Familiarity with the villagers resulting from our continuous residence in the community produced a high level of co-operation. All the sample households were visited and interview was carried out with eligible women in the selected households. There were a total of 420 eligible women in the selected households, 17 households are residing in far away distance and other five refused cases to be interviewed in spite of sincere efforts. Cross tabulation and logistic regression analysis was resorted to find out the effect of socio-economic and demographic variables on son preference and contraceptive practice among the sample areas.

\section{http://repository.uwc.ac.za}




\section{Study Setting}

The Nilgiris district has one of the largest concentrations of hill tribal population in rural Tamilnadu, south India has been selected for the present study. This is because this district has some special features like hilly area majority of the areas under forest cover and tea and coffee plantations (estates), higher concentration of tribal groups, tourist attraction and so on. Many tribal communities live in the whole mountain ranges of this district. The majority of the communities are Toda, Kota, Kurumba, Irula and Paniya. There are four taluks namely, Udhagamandalam (Ooty), Coonoor, Gudalur and Kotagiri. In all these four taluks one or more of these tribal communities live in considerable number, hamlets / settlements. The today many tribal settlements are not easily accessible by road or by any other transport. There are four Panchayats were purposively selected for the present study in order to include sufficient sample number of all the tribal groups from each taluk. The basic amenities like electricity, schools, hospitals, transportation, sanitation, protected water supply, etc., are rarely available to these areas. Especially, these kinds of things not at reached in Kurumba and Irula areas. Most of them don't have door numbers or ration card or any other official regards. Because these tribal groups are living in deep forest and it should be very far away from the town/village. During survey period respondents were mentioned that nobody is officially visited in this particular hamlets. Most of the families live in kuchha / tiled houses in forest area. A large number of proportion are agricultural and tea plantation laborer. Tribal people don't bother about their children's education. Their children also involved in agricultural or other related activities. At the same sons are considered as, their parents' only source of economic security in old age. If sons also doing work along with their parents it should be economically benefited for them. If you have more number of sons, you have more hands you are getting more money you are getting more money. This is a major concept of them. And on the other hand, particularly where women have little economic independence or cannot inherit property, sons are regarded as a great asset to compensate the loss of her husband's support due to death or desertion. The women lower income does not invest household resource in female children because they marry and leave the family, at some stage and is likely to have little pay off. So poor families tend to invest what little they have in sons. Under these circumstances it is particular interest to explore this aspect influence of sex preference among the tribal communities. This exploration will be more authentic if their fertility behavior with respect to son preference is compared with that of the tribal groups.

\section{The Research Problem}

Socio-economic factors among tribal groups and its influence on fertility and contraceptive practice are interesting for the study. It is widely recognized among women's education is positively related to socio-economic development and also fertility change. The level of education is very low, especially in the case of women and even a bit of education; do not show any reduction in the fertility behavior especially between Kurumba and Irula groups. At the same time, these two groups never bother about educating the children. Similarly, young mothers could be expected to have a lesser degree of son preference than the elder because of the various Tamilnadu State. Structured questionnaire was used for data collection. The investigator was able to visit and

\section{http://repository.uwc.ac.za}


interview only 398 houses as their households are residing in far away distance, which could not be reached easily. The purpose was to compare the differentials in their background characteristics, which may have an influence on son preference and reproductive behavior. Although pre-tested questionnaires were the main instruments used, qualitative information was gathered informally to supplement the findings of the inquiry. Familiarity with the villagers resulting from our continuous residence in the community produced a high level of co-operation. All the sample households were visited and interview was carried out with eligible women in the selected households. There were a total of 420 eligible women in the selected households, 17 households are residing in far away distance and other five refused cases to be interviewed in spite of sincere efforts. Cross tabulation and logistic regression analysis was resorted to find out the effect of socio-economic and demographic variables on son preference and contraceptive practice among the sample areas.

\section{Study Setting}

The Nilgiris district has one of the largest concentrations of hill tribal population in rural Tamilnadu, south India has been selected for the present study. This is because this district has some special features like hilly area majority of the areas under forest cover and tea and coffee plantations (estates), higher concentration of tribal groups, tourist attraction and so on. Many tribal communities live in the whole mountain ranges of this district. The majority of the communities are Toda, Kota, Kurumba, Irula and Paniya. There are four taluks namely, Udhagamandalam (Ooty), Coonoor, Gudalur and Kotagiri. In all these four taluks one or more of these tribal communities live in considerable number, hamlets / settlements. The today many tribal settlements are not easily accessible by road or by any other transport. There are four Panchayats were purposively selected for the present study in order to include sufficient sample number of all the tribal groups from each taluk. The basic amenities like electricity, schools, hospitals, transportation, sanitation, protected water supply, etc., are rarely available to these areas. Especially, these kinds of things not at reached in Kurumba and Irula areas. Most of them don't have door numbers or ration card or any other official regards. Because these tribal groups are living in deep forest and it should be very far away from the town/village. During survey period respondents were mentioned that nobody is officially visited in this particular hamlets. Most of the families live in kuchha / tiled houses in forest area. A large number of proportion are agricultural and tea plantation laborer. Tribal people don't bother about their children's education. Their children also involved in agricultural or other related activities. At the same sons are considered as, their parents' only source of economic security in old age. If sons also doing work along with their parents it should be economically benefited for them. If you have more number of sons, you have more hands you are getting more money you are getting more money. This is a major concept of them. And on the other hand, particularly where women have little economic independence or cannot inherit property, sons are regarded as a great asset to compensate the loss of her husband's support due to death or desertion. The women lower income does not invest household resource in female children because they marry and leave the family, at some stage and is likely to have little pay off. So poor families tend to invest what little they have in sons. Under these circumstances it is particular interest to explore this aspect influence of sex preference among the tribal communities. This exploration will be more authentic if 
their fertility behavior with respect to son preference is compared with that of the tribal groups.

\section{The Research Problem}

Socio-economic factors among tribal groups and its influence on fertility and contraceptive practice are interesting for the study. It is widely recognized among women's education is positively related to socio-economic development and also fertility change. The level of education is very low, especially in the case of women and even a bit of education; do not show any reduction in the fertility behavior especially between Kurumba and Irula groups. At the same time, these two groups never bother about educating the children. Similarly, young mothers could be expected to have a lesser degree of son preference than the elder because of the various modernization influences including the concept of the small family size. But this hypothesis appears to be true only in the case of Toda groups than in the other groups, which need to be looked in to. Those tribal groups engaged in the traditional viz., collection of forest products and other occupations like agricultural labor and working on one's found among couples who are engaged in non-traditional sector of employment namely trade and commerce and other services and also couples who are confined themselves to household work. The influence of socio- economic factors, therefore have been considered as important variables in the present study. The influence of this factor on son preference and contraceptive practice will be examined for the group of tribal women. If the net utility of having son out weigh that of a daughter, parents are likely to prefer sons to daughters. A complex interplay of economic and socio-cultural factors determines the benefits and costs of a child and son preference.

\section{Profile of the Sample}

According to the 2001 census the population of Nilgiris district is slightly more than 7 lakhs of which 3.53 lakhs are males and 3.50 lakhs are females and thus males are just little over 50 percent. The district's share of population in Tamilnadu state is 1.27 only, which is the lowest in Tamilnadu and this increase is around 11.85 per cent for the decade as a whole. The Nilgiris district is covered by with magnificent forests with varied colorful culture Ootacamund (old name) Udhagamandalam enjoys a salubrious climate. Forests wealth is one of the factors, adding to the nature beauty and economic importance of these districts. The study of the Nilgiris district has some special features like hilly area majority of the area under forest cover and tea and coffee plantations estates higher concentration of scheduled tribe population, tourist attraction and so on. Under these circumstances it is very interesting to know the son preference and contraceptive practices of tribal groups, socio-economic and demographic characteristics of its over a period of time.

The district derives its name from its natural setting high above the sea level situation at the junction of the two-ghat ranges of the Sayadri hills Nilgiris district provides a fascinating view. The steep hills and fantastically narrow valleys with numerous rivers and rivulets running in all directions with a few fine waterfalls here and there provide beautiful scenery. The temperate and most equable climate further heightens the attractiveness of the place. The importance of the district is not confined to its beautiful scenery and climate alone. The rain that falls in this district is of great value and economic 
importance. The district is drained by numerous streams and the two major rivers that originate from this district are the Bhavani in the south and the Mayar in the north. Pykara River, after traversing along the border of Udhagamandalam and Gudalur taluks joins the river Mayar. The Kundha River rising in the sleep slopes of the hill collecting all the minor streams that rise drains Kundah valley, the Nanjanad valley, the beautiful Emerald valley and also a portion of Udhagamandalam taluk. The water of these rivers has been fruitfully harnessed for the establishment of three hydroelectric projects at Pykara, Mayar and Kundah. The soil of the district falls under three major types:clay, classy loam with laterite sub-soil. The depth of the soil usually varies from one to three feet and sub-soil is invariably process. The district receives a normal rainfall of $1920.8 \mathrm{~mm}$ during a year. Which is the highest rainfall received by all the remaining district of Tamilnadu.

\section{Information about Tribal Communities}

The majority of the tribals living in Nilgiris district, Tamilnadu are Toda, Kota, Kurumba, Paniya and Irula, who are inhabitants there for centuries. They were spoken a language of the Dravidian family of languages. The Toda tribal community has entirely different from (socially and culturally) other tribes. Other tribes are mostly which is used in the Tamil language for conversation. However, a lot of studies on various tribal groups at various aspects have been carried out in this study. But studies on tribal sex preference, especially son preference and contraceptive practices are very limited. Almost all the women folk were afraid of Tubectomy because they thought it is dangerous and fatal to their health. The government and non- government agencies should explain them about an advantage and benefits of such program to clear their fears; appropriate population/health education should be given to them. A majority of the tribal groups (87 per cent) were living in joint family units; two - third of the tribes were without schooling and the extent of indebtedness was high among these groups. And lower mean age at marriage among the wives of the groups (13.4) years and lower mean age at first birth (17.8) years, an average a women gave a higher fertility level (5.32) children and higher family size (4.12). All mortality events showed high rates among the Irula women and 52 per cent of them had experienced some forms of pregnancy wastage including infant and childhood mortality. This was mainly due to the available reasons such as infection diseases, malnutrition and lack of medical care and unhygienic conditions. The lack of parental interest in sending children to schools was because children provided economic assistance for the family. Since more than 80 per cent of the children were reported to be engaged in agricultural and related activities. Parents like to depend on their sons for old-age security than their daughters. The cost of bringing up children up to age 15 does not seem to vary much between sons and daughters. However, the expectations from sons appeared to be more as compared to the daughters.

\section{Findings}

An analysis of the socio-economic and demographic characteristics of the currently married tribal women shows that most of the 98 per cent were Hindus and the majority 80 per cent of the women belonged to low caste group. Most of the couples using protected water like piped, hand pump and well water. Most of the families have household annual income of less than 20000 rupees or more. As regards occupation of the couples (both men and women) in the tribal area, a large proportion are agricultural and tea 
plantation laborers. The low fertility is found among couples who are engaged in non-traditional sector of employment namely trade/ commerce and other services. In addition to trade/ commerce and other government service couples that are confined themselves to household work, also show relatively lower fertility than the other traditional occupational groups. Below 50 per cent of the households have tiled houses. 23 per cent have been educated up to primary level (Table 1).

More than 60 per cent are illiterates. The level of education is very low, especially in the case of female and even a bit of education did not show any reduction in the fertility behavior of tribal groups. A substantial proportion of tribal women got married between 15-24 years of age and the proportion of women married in the age group of less than 14 and more than 24 are quite low. Young mothers could be expected to have a lesser degree of son preference than the elder because of the various modernization influences including the concept of the small family. But this hypothesis appears to be true only in the case of Toda groups. Though the younger women of other tribes exhibit greater size preference than in Toda tribes, their son preference is significantly higher. A tribal child starts contributing to the family income directly or indirectly from the age of 7 to 8 years. The study reveals that about 65 per cent of the children started contributing financially to their family right from 9 to 10 years. The mean age at marriage of the wives is the lowest 17.8 years for tribal groups. The average number of wanting more children in schedule tribe was 1.06 per cent. Majority of the women 63 per cent were non-users of contraceptives and remaining 37 per cent were users of one or the other method of contraception. Among the users 29 per cent were using temporary methods.

Majority of the women 54 per cent are non- users of contraceptives and the remaining 46 per cent are users of one or other method of contraception. Among the users has 38 per cent are acceptors of sterilization method while the remaining 8 per cent are using temporary methods namely, IUD 2 per cent, condom 1.5 per cent and oral pills and other users (in Table 2).

Among the 49 per cent of women have expressed two children as desired family size. 30 per cent of sterilized women have expressed two children as desired family size. While, 43 per cent desire three children among sterilized. Only 7 per cent desired for four or more children. The desired family size expressed is not very high among them, than among the non-users. There is relationship between desired family size and contraceptive use it shows.

The proportion of contraceptive methods users increases and reaches the maximum 43.2 per cent in the age group of 20-24 and decreases thereafter while 42 per cent in the age 25-29 (in Table 3 ).

The proportion of users is higher in 20-24 age group of these women have 42.4 per cent are acceptors of sterilization method. In age 25-29, 45 per cent are acceptors of sterilization method. Majority of the tribal women in the age 15-19 group are not using any method; 45 per cent adopted sterilization method and the remaining have used other temporary methods. 47 per cent of women in age 20-24 are non-users. 
Table 1: Socio-economic and demographic characteristics of the tribal groups

\begin{tabular}{|c|c|c|c|c|c|}
\hline $\begin{array}{l}\text { Socio-economic } \\
\text { characteristics of } \\
\text { the household }\end{array}$ & $N=398$ & $\%$ & $\begin{array}{l}\text { Demographic } \\
\text { characteristics of the } \\
\text { household }\end{array}$ & $N=398$ & $\%$ \\
\hline Religion & & & Age of Wives & & \\
\hline Hindu & 346 & 86.9 & $15-24$ & 283 & 71.1 \\
\hline Non-Hindus & 52 & 13.1 & $25-34$ & 132 & 25.6 \\
\hline Housing Condition & & & $35+$ & 13 & 3.3 \\
\hline Hut & 81 & 20.6 & Age at Marriage & & \\
\hline Kutcha & 67 & 16.8 & $15-19$ & 58 & 14.6 \\
\hline Pucca & 56 & 14.1 & $20-24$ & 270 & 67.8 \\
\hline Tiles & 194 & 48.7 & $25-29$ & 64 & 16.1 \\
\hline Electrification & & & $30+$ & 6 & 1.5 \\
\hline Yes & 187 & 47 & Age of Husband & & \\
\hline No & 211 & 53 & $15-24$ & 285 & 71.6 \\
\hline Water Sources & & & $25-34$ & 100 & 25.1 \\
\hline Piped water & 153 & 34.4 & $35+$ & 13 & 3.3 \\
\hline Well water & 164 & 41.2 & Living Children & & \\
\hline Hand pump & 32 & 8.1 & 1 & 12 & 3 \\
\hline Other sources & 49 & 12.3 & 2 & 85 & 21.4 \\
\hline Education of Wives & & & 3 & 179 & 45 \\
\hline Illiterate & 242 & 60.8 & 4 & 82 & 20.6 \\
\hline Primary school & 92 & 23.1 & 5 & 30 & 7.5 \\
\hline Middle school & 46 & 11.6 & 6 & 7 & 1.8 \\
\hline Sec. School & 14 & 3.5 & $7+$ & 3 & 0.8 \\
\hline Higher secondary & 3 & 0.8 & Causes of Child Mortality & & \\
\hline Degree and above & 1 & 0.3 & No disease & 367 & 92.2 \\
\hline Total Annual Income (in rupees) & & & Dysentery & 9 & 2.6 \\
\hline$<4999$ & 112 & 28.1 & Malaria & 6 & 1.5 \\
\hline $5000-9999$ & 24 & 6 & Chicken box & 2 & 0.5 \\
\hline $10000-14999$ & 120 & 30.2 & Unspecified & 14 & 3.5 \\
\hline $15000-19999$ & 79 & 20 & Total no. of deaths reported & 31 & 7.8 \\
\hline $20000>$ & 63 & 16 & Want More Children & & \\
\hline Occupational Status & & & 1 & 211 & 53 \\
\hline Agricultural laborer & 383 & 96.2 & 2 & 166 & 41.7 \\
\hline Cultivator & 8 & 2 & 3 & 12 & 3 \\
\hline Trade/commerce & - & - & 4 & 7 & 1.8 \\
\hline Others & 7 & 1.8 & $5+$ & 2 & 0.5 \\
\hline Irrigation & & & Prefer First Boy & & \\
\hline Yes & 151 & 38 & Yes & 260 & 65.3 \\
\hline No & 247 & 62 & No preferred girl & 12 & 3 \\
\hline Landholding Size (in acres) & & & No preference & 126 & 31.7 \\
\hline 0 & 212 & 53.3 & Reason for Son & & \\
\hline 1 & 81 & 20.4 & Income purpose & 208 & 72.4 \\
\hline 2 & 43 & 10.8 & Keeping family line & 102 & 25.6 \\
\hline 3 & 21 & 5.3 & Old age security & 8 & 2 \\
\hline 4 and above & 41 & 10.3 & & & \\
\hline
\end{tabular}

Table 2: Percentage distributions of women using contraceptive methods by desired family size (DFS)

\begin{tabular}{|c|c|c|c|c|c|c|}
\hline \multirow[t]{2}{*}{$D F S$} & \multicolumn{6}{|c|}{ Contraceptive methods } \\
\hline & Non-users & Sterilization & $I U D$ & Condom & Oral pillsand others & Total \\
\hline 1 & 22.0 & 20.0 & - & - & - & 77 (19.3) \\
\hline 2 & 48.6 & 30.0 & 12.5 & 33.3 & 21.1 & $156(39.2)$ \\
\hline 3 & 24.3 & 43.0 & 37.5 & 16.7 & 79.0 & $136(34.2)$ \\
\hline 4 & 3.3 & 6.0 & 50.0 & 50.0 & - & $23 \quad(5.8)$ \\
\hline 5 & 1.9 & - & - & - & - & $(1.0)$ \\
\hline $6+$ & - & 1.3 & - & - & - & $(0.5)$ \\
\hline Total & $4(53.8)$ & $151(38.0)$ & $8(2.0)$ & $6(1.5)$ & $19(4.8)$ & $(100.0)$ \\
\hline
\end{tabular}

Parenthesis indicate percentage

Those women in age group 24-29 has 45 percent are using sterilization method. Of them 35 per cent of women are non-users. Among the condom users 67 per cent and among Oral pills users 5.3 per cent are in the group of 20-24 (in Table 4). Among the age group 2529 of 29 per cent had adopted sterilization method, only 18 per cent are non- users. In age group 30-34 of 24 per cent are a non- user. Among, these groups of women 22 per cent have adopted sterilization. 50 per cent of women using IUD are in the same age group. 
In Table 5 the first three important reasons reported in highest proportion are wanted to have as many as children as 41 per cent, second reason is that have women did not get the desired sex 18 per cent and third reason which is lack of knowledge 18 per cent. The proportion of first reason increases sharply between age group of 15-19 and 25-29 and decreased thereafter. Majority 49 per cent at age 20-24 have not get the desired sex. It is clear that the currently married women who are in the younger age and have not achieved the desired sex composition have not adopted contraceptive method. 33 per cent of women at age 25-29 had lack of contraceptive knowledge. The third major reasons have been almost reported in all the age group (young and elder women). 23 per cent of women in 30-34years of age have reason, as society does not approve.

\section{Table 3: Percentage distribution of women using contraceptive methods} by age of women

\begin{tabular}{lcccccc}
\hline $\begin{array}{l}\text { Age of } \\
\text { women }\end{array}$ & \multicolumn{7}{c}{ Contraceptive methods } \\
\cline { 2 - 7 } & Non-users & Sterilization & IUD & Condom & Oral pills and Others & Total \\
\hline $15-19$ & 0.5 & - & - & - & - & 1 \\
$20-24$ & 46.7 & 42.4 & - & 16.7 & 36.3 & 172 \\
$25-29$ & 38.3 & 45.0 & 37.5 & 33.3 & 63.2 & 167 \\
$30-34$ & 12.1 & 10.6 & 62.5 & 33.3 & - & $49.0)$ \\
$35-39$ & 2.3 & 2.0 & - & 16.7 & - & $9(12.3)$ \\
$40+$ & - & - & - & - & - & - \\
\hline Total & $214(53.8)$ & $151(37.9)$ & $8(2.0)$ & $6(1.5)$ & $19(4.8)$ & $398(100.0)$ \\
\hline
\end{tabular}

Parenthesis indicate percentage

Table 4: Percentage distribution of women using contraceptive methods by age at marriage

\begin{tabular}{lcccccr}
\hline $\begin{array}{l}\text { Age of } \\
\text { women }\end{array}$ & \multicolumn{7}{c}{ Contraceptive methods } \\
\cline { 2 - 7 } & Non-users & Sterilization & IUD & Condom & Oral pills and Others & Total \\
\hline $15-19$ & 18.7 & 1.3 & - & - & - & 42 \\
$20-24$ & 35.0 & 45.0 & - & 66.7 & 5.3 & $148.6)$ \\
$25-29$ & 17.8 & 29.1 & 25.0 & 33.3 & 89.5 & $103(26.0)$ \\
$30-34$ & 23.8 & 22.0 & 50.0 & - & 5.3 & $89(22.4)$ \\
$35-39$ & 4.7 & 2.6 & 25.0 & - & - & 16 \\
\hline Total & $214(53.8)$ & $151(38.0)$ & $8(2.0)$ & $6(1.5)$ & $19(4.8)$ & $398(100.0)$ \\
\hline
\end{tabular}

Parenthesis indicate percentage

Table 5: Percentage distribution of tribal women by age and reason for nonacceptance

\begin{tabular}{|c|c|c|c|c|c|c|c|c|}
\hline \multirow[t]{2}{*}{ Reason for Non-acceptance } & \multicolumn{5}{|c|}{ Tribal women age group } & \multirow[b]{2}{*}{$40+$} & \multirow{2}{*}{\multicolumn{2}{|c|}{ Total }} \\
\hline & $15-19$ & $20-24$ & $25-29$ & $30-34$ & $35-39$ & & & \\
\hline Fear of side effects & - & 2 & 5 & 13 & 16 & 22 & 13 & $(6.1)$ \\
\hline Cost of contraceptives & - & - & - & 7 & 8 & - & 4 & (2) \\
\hline It is against religion & - & - & - & - & 12 & 11 & 4 & (2) \\
\hline Society does not approve & 4 & 5.3 & 14.3 & 23 & 8 & 11 & 21 & $(10)$ \\
\hline It is against nature & - & - & - & - & 12 & - & 3 & (1.4) \\
\hline \multicolumn{9}{|l|}{ Just I wanted to have } \\
\hline as many as children & 71 & 23 & 43 & 33 & 32 & 35 & 88 & $(41.1)$ \\
\hline Did not get the desired sex & 16 & 49 & - & - & 41 & 22 & 39 & $(18.2)$ \\
\hline Choose to use natural method & - & 2 & - & - & - & - & 1 & $(0.5)$ \\
\hline Elders are against it & - & - & 5 & - & - & - & 2 & (1) \\
\hline Lack of knowledge & 10 & 19.3 & 33 & 23.3 & 8 & - & 39 & $(18.2)$ \\
\hline Any other reasons & - & - & - & - & - & - & - & \\
\hline Total & $51(24)$ & $57(27)$ & $42(14)$ & $30(14)$ & $25(12)$ & $9(4.2)$ & 214 & $(100)$ \\
\hline
\end{tabular}

Parenthesis indicate percentage

The proportion of women with fear (about sterilization) of side effects is higher 22 per cent in tribal women aged 40+. About 46 per cent of women use birth control methods, mostly female sterilization 38 per cent. Temporary method users are below 9 per cent. 31 per cent of women using permanent method with four living children and temporary methods 
users which is women having two and three living children are more or less same in above 30 per cent. All method users having three children women are 43 per cent.

Overall 46 per cent of the women are using any one of the methods. 54 per cent of the women are non-users (in Table 6). It will not be out of place to point out some of the opposing interests as evident in Table 7. Compare the case of two sons and two daughters 59 per cent families of parity two. While the proportion of sterilized women was higher among two sons category, it is the contraceptive users are in greater proportion between two daughters' families. Evidently the latter group does not want to close the option of having a son. A case where son preference and family size preference exerting equal and opposite influences, the desire to have at least one son 3 per cent. Also weights high, as the example of one daughter one son 24 per cent and two daughters one son 52 per cent families indicate (in Table 7). Next to the desire to have at least one son is the desire to have families with children of both the sexes:observes the percentage of acceptors among the two sons one daughter 57 per cent and two daughters one son 52 per cent families. Similarly one son two daughters group is typical of families desiring to have two sons but ending up with two daughters, probably and then family size preference becoming stronger.

The findings of table 7 suggest that the presence of strong son preference as well as size preference appears to be stronger among the tribal women.

\section{Regression Analysis}

Coefficient and odds ratio for currently married women and currently using any contraceptive method aged 15-49 years for Nilgiris district has obtained from the analysis.

\section{Table 6: Percentage distribution of families according to sex combination and percentage accepting \\ Contraceptives}

\begin{tabular}{|c|c|c|c|c|c|c|c|}
\hline \multirow{2}{*}{$\begin{array}{l}\text { Number } \\
\text { of Living } \\
\text { children }\end{array}$} & \multicolumn{7}{|c|}{ Temporary method users } \\
\hline & $\begin{array}{l}\text { Permanent } \\
\text { method users }\end{array}$ & $\begin{array}{l}\text { Temporary } \\
\text { method users }\end{array}$ & $\begin{array}{c}\text { All method } \\
\text { users }\end{array}$ & Non-users & Total & Sam & le size \\
\hline 1 & 0.7 & - & 0.5 & 4.2 & 100.0 & 10 & (3) \\
\hline 2 & 12 & 30.3 & 15.2 & 26 & 100.0 & 83 & $(21)$ \\
\hline 3 & 46 & 30.3 & 43 & 53.3 & 100.0 & 193 & (49) \\
\hline 4 & 31 & 21.2 & 29.3 & 8.4 & 100.0 & 72 & $(18)$ \\
\hline 5 & 8 & 18.2 & 10 & 6.1 & 100.0 & 31 & (8) \\
\hline $6+$ & 3 & - & 2.2 & 2.3 & 100.0 & 9 & $(2.3)$ \\
\hline Total & $151(38)$ & $33(8.3)$ & $184(46.2)$ & $214(54)$ & 100.0 & 398 & $(100)$ \\
\hline
\end{tabular}

Parenthesis indicate percentage 
Table 7: Distribution of families according to gender combination and percentage accepting contraceptives

\begin{tabular}{lccccccc}
\hline $\begin{array}{l}\text { Type of gender } \\
\text { contraceptive }\end{array}$ & $\begin{array}{c}\text { Acceptance of } \\
\text { sterilization }\end{array}$ & $\begin{array}{c}\text { Acceptance of } \\
\text { other methods }\end{array}$ & $\begin{array}{l}\text { Non- } \\
\text { users }\end{array}$ & All users & Total & Sample size \\
\hline S-0 & 3.12 & 25.38 & 71.50 & 28.50 & 100.00 & 10 & 26 \\
0-D & 0.56 & 34.71 & 64.73 & 35.27 & 100.00 & 16 & 132 \\
SS-0 & 36.23 & 27.16 & 36.61 & 63.39 & 100.00 & 12 & 132 \\
S-D & 23.55 & 37.80 & 38.65 & 61.35 & 100.00 & 110 & 10 \\
0-DD & 17.60 & 23.42 & 38.98 & 41.02 & 100.00 & 07 & 109 \\
SSS-0 & 65.25 & 14.14 & 20.61 & 79.39 & 100.00 & 80 & \\
SS-D & 57.30 & 09.11 & 33.59 & 66.41 & 100.00 & 01 \\
S-DD & 52.07 & 12.73 & 35.20 & 64.80 & 100.00 & 131 \\
0-DDD & 44.80 & 14.38 & 14.82 & 59.18 & 100.00 & 07 \\
SSSS-0 & 63.63 & 17.76 & 18.61 & 81.39 & 100.00 & 07 \\
SSS-D & 57.90 & 20.11 & 21.99 & 78.01 & 100.00 & 37 \\
SS-DD & 58.45 & 18.70 & 22.85 & 77.15 & 100.00 & 71 \\
S-DDD & 41.56 & 19.30 & 39.04 & 60.96 & 100.00 & 14 \\
0-DDDD & 36.60 & 03.22 & 60.18 & 39.82 & 100.00 & 02 \\
\hline
\end{tabular}

$\mathrm{S}=$ Son, $\mathrm{D}=$ Daughter

Sex combination of living children as an independent variable, depends on contraceptive use among tribal women of the sample areas. As that sex composition of living children for various categories as follows like one son, two daughters, two sons, three or more children (among both of the sex), all daughters, all sons, son less than daughter, son greater than daughter and son is equal to daughter has been fitted in the logistic regression analysis. All the women were having at least one child irrespective of the sex (in Table

8).

Table 8: Logistic regression coefficient and odds ratio for currently using women by any contraceptive method

\begin{tabular}{lcc}
\hline Variables & $\begin{array}{c}\text { Use of contraception } \\
\beta \text { coefficient }\end{array}$ & $\begin{array}{c}\beta \\
\text { coefficient }\end{array}$ \\
\hline $\begin{array}{l}\text { Sex composition } \\
\text { of living children }\end{array}$ & & \\
$\quad$ Ref:(one son and & & \\
$\quad$ one daughter) & & \\
One daughter & $0.2991^{*}$ & 1.3487 \\
One son & -0.1169 & 0.8897 \\
Two daughters & $0.2470^{* *}$ & 1.2802 \\
Two sons & $-0.5858^{* * *}$ & 0.5566 \\
Three or more children & na & na \\
All daughters & na & na \\
All sons & -0.0116 & 0.9885 \\
Sons<daughter & $-1.4902 * * *$ & 0.2253 \\
Son>daughter & $0.3939 *$ & 1.4828 \\
Son = daughter & -0.2991 & 0.7415 \\
Constant & 2.5771 & \\
-2 Log Likelihood & 525.3105 & \\
No. of observation & 398 & \\
\hline
\end{tabular}

${ }^{*} \mathrm{p}<01 * * \mathrm{p}<05 * * * \mathrm{p}<001$

Note: na=not applicable

Present study shows that the more sons a family has less likely it was to conceive an other child, because it was more likely to have satisfied its preference for sons. It shows son 
preference is marginally high in the tribal groups. In the case of category of son>daughter the odds are greater among tribal women. These entire variables again conform that there is a tendency among tribal groups for son preference.

\section{Conclusion}

The present study is an attempt to find out the reproductive behaviour in relation to their son preference and contraceptive practice an answer to the general query-how the tribal groups differ from their various socio-economic and demographic characteristics while inhabiting in the same ecosystem. Limited number of related literature lead to conclude that the theoretical explanations advanced for some expected relationship between level of development socio- economic and cultural and value of children are sound. But the empirical relationships obtained in various setting always do not support the expected relationships. The fertility differentials in the level are due to differentials in the value of sons and daughters child, which are likely to be different under Indian context. A strong preference for sons in the society and at the same time girl children is considered expensive because of increasing dowry. It is necessary to study the son preference among these groups. To examine the son preference among these groups, it is important that we consider with developed and under developed community groups. To this study, the tribal women with respect to their influence of socio-economic, demographic factors on son preference and contraceptive practice. Respondents of both sexes perceived sons contribute to the satisfaction of a greater number of values and needs than daughters. Financial security, being accepted by others, having a happy home, personal achievement and carrying on the family name were all values that respondents associated more with sons than with daughters. The preference for sons that has been observed to varying degrees in every part of India has been showed to have an adverse effect on both fertility behaviour and sex differentials in child mortality. The desire for sons discourages some couples from discontinuing childbearing after reaching their desired number of children because they have not yet had their minimum desired number of sons. When couples have achieved desired number of sex particularly sons, they adopt sterilization or other temporary methods of contraception.

More sons are considered as a conservative concept present in several traditional cultures and so is a factor that acts against birth control. To some extent this presumption is true. However, the result of the study show that even when the cultural constraints are overcome, as by the Hindus, in this study, son preference can still exist for economic reasons. For the very poor grown up sons are sources of income for the family and also for it stability. On the other hand, daughters not only prove themselves a liability when young and when they reach the capacity to earn, they will be earning for their husbands' family. It is natural therefore, that for the poor sons are an asset and sons are strength of village as well as whole family and so are preferred. By and large women have been found to be most satisfied with the combination of at least two sons and one daughter. Tribal women are more willing to enlarge their family size. No systematic relationship has been found between son preference and number of living children. 


\section{References}

Arnold Fred, Minja Kim Choe and T. K. Roy. 1998. "Son preference, the family building process and child mortality in India.” Population Studies, 52(3): 301315 .

Asari, V.G.K. and A. Sathiya Susuman. 1998. "Reproductive behavior of women in declining fertility:A sample study of married women in reproductive ages in Kerala." Journal of Health and Population Perspectives and Issues, 21(2): 91103.

Coombs C H, Lolagane C, Coombs and G. M. Mc Clelland. 1995 "Preference scales for number and sex of children.” Population Studies, 29 (2): 273-298.

Gurumurthy G. 1986. "The study of mortality in relation to fertility among Yanadis; A tribal community of adoption of family planning." Journal of Social Welfare, 34(11): 24-25.

Gurusamy, P. A. 1988. "Irula Tribes of Nellithorai- Coimbatore District." Journal of Social Welfare, 33(2): 34-35.

Karkal, Pause. 1979. "Education of children among Scheduled Tribes", in K. Srinivasan, P. C. Saxena and Tara Kanitkar (eds.) Demographic and Socioeconomic aspects of the child in India, Bombay Himalaya Publishing House.

Krishnan, V. 1993. "Gender of children and contraceptive use." Journal of Biosocial Sciences, 25(2): 9-17.

Krishnamoorthy, S. 1974. "Effects of sex preference and mortality on family size." Demography India, 3(1):120-132.

Kuriyan, J. 1982. "Tribal Health Programs." Journal of Health and Population Perspective and Issues. 5(4):323-336.

Muthurayappa, R.M. Choe, Fred Arnold and T. K. Roy. 1997. "Son Preference and Its Effect on Fertility in India." National Family and Health Survey, Subject Reports, No. 3 Mumbai and Honolulu:International Institute for Population Sciences and East West Center.

Nag, Moni. 1991. "Sex preference in Bangladesh, India and Pakistan and its effects on fertility." Journal of Demography India, 20(2):163-185.

Rajan S Irudaya, U. S. Mishra and T. K. Vimala. 1996. "Choosing a permanent contraceptive does son preference matter?" Economic and Political Weekly, XXXI(29): 1980-1984.

Rajaretnam, T. 1995. "Family size desire, sex preference, socio-economic condition and contraceptive use in rural Karnataka, India.” Demography India, 24(2):275290.

Rajaretnam T and R. V. Deshpande. 1994b. "The effect of sex preference on contraceptive use and fertility in rural South India." International Family Planning Perspectives, 20(3):88-95.

Ramu, G. N. 1988. Family Structure and Fertility Emerging Patterns in an Indian City. Sage Publication, New Delhi.

Registrar General. 2001. Census of India, Total Population Table, Tamilnadu. Registrar General, Chennai, Tamilnadu.

Repetto, R. G. 1972. "Son preference and fertility behavior in developing countries." Studies in Family Planning, 3:177-189.

Sadasiva, K. Rao. 1977. "A study on the demographic and socio-cultural aspects of the tribes of Manipur Tribe.” Manipur, 1-10. 
Sarma D V N and Anrudh K. Jain 1974. "Preference about sex of children and use of contraception among women wanting no more children in India." Demographic India, 3(1): 81-104.

Sathiya Susuman, A. and G. K. Asari. 2001. "Reproductive health care of women in rural areas:An exploratory study in Nilgiris District, Tamilnadu." Journal of Family Welfare, 47(1):50- 55.

Sathiya Susuman, A. 2000. "Index of gender preference, contraceptive practice and fertility:A multivariate analysis." Paper presented in Indian Association for the Study of Population, Millennium Conference at New Delhi.

Saxena, D. N. 1982. Fertility and Family Planning Among Two Tribal Communities of Uttar Pradesh. Series B:Survey Report, No. 13, Population Research Center, Lucknow, 85.

Srinivasan, P., C. Sexena and T. Kanitkar. 1982. Demographic and SocioEconomic Aspects of the Child in India. Himalaya Publishing House, Bombay. Varadarajan, D 1981. "A demographic survey of Kotas of Nilgiris District, Tamilnadu." Journal of Family Welfare, 27(3):25-29.

Vlassoff, M. and C. Vlassoff. 1980. "Old age security and children in rural India." Population Studies, 34: 487-499. 